\title{
Т.С. Вацеба ${ }^{1}$, Л.К. Соколова ${ }^{2}$, В.В. Пушкарьов ${ }^{2}$,
} О.І. Ковзун ${ }^{2}$, В.М. Пушкарьов ${ }^{2}$, М.Д. Тронько ${ }^{2}$

${ }_{1}^{1}$ ДВНЗ “Івано-Франківський національний медичний університет”

2 ДУ “Інститут ендокринології та обміну речовин ім. В.П. Комісаренка НАМН України”, Київ E-mail: pushkarev.vm@gmail.com

\section{Активація протеїнкінази p70S6K1 у мононуклеарних клітинах крові хворих на рак та діабет}

Представлено членом-кореспондентом НАН Украйни М.Д. Троньком

Сигнальний каскад IRS/PI3K/Akt/mTOR/p70S6K контролює ріст клітин та гомеостаз у відповідь на сигнали середовища, такі як рівень амінокислот, глюкози, енергіі, кисню, та дію ростових факторів. Прикінцевою ланкою цього каскаду є протеїнкіназа р70S6K, яка контролює синтез білка, біогенез рибосом, клітинний цикл, апоптоз, сплайсинг мРНК та інші важливі процеси. Порушення регуляції каскаду PI3K/Akt/mTOR/ p70S6К може спричинити виникнення таких важких захворювань, як рак, ожиріння $і$ діабет 2-го типу 3 ускладненнями.

Вивчали активацію р70S6K1 у мононуклеарних клітинах крові (РМВC) хворих на рак та діабет методом імуноферментного аналізу. Показано, що у РМВС хворих на рак та діабет фосфорилювання p70S6K1 (Тре389) зростає, що свідчить про активацію кінази, яка відіграє важливу роль у формуванні інсулінорезистентності та прогресії пухлин. Це, можливо, пов'язано з підвищеним рівнем інсуліну та IGF-1 у крові цих хворих. Проте у онкологічних хворих на діабет фосфорилювання р70S6K1 та, відповідно, ï активність істотно знижуються порівняно з показниками у хворих на рак або діабет. Обговорюються механізми такого зниження активності р70S6K1.

Ключові слова: діабет 2-го типу, рак, мононуклеарні клітини периферичної крові, р70S6К1.

Сигнальний каскад PI3K/Akt/mTOR/p70S6K керує ростом клітин та гомеостазом, у тому числі синтезом білка, ліпогенезом, обміном глюкози, аутофагією, біогенезом лізосом, проліферацією та виживанням, у відповідь на сигнали середовища, такі як рівень амінокислот, глюкози, енергії, кисню, та дію ростових факторів [1]. Прикінцевою ланкою цього каскаду є протеїнкіназа p70S6K, яка контролює синтез білка, біогенез рибосом, клітинний цикл, апоптоз, сплайсинг мРНК та інші важливі процеси. Еволюційно консервативні протеїнкінази рибосомного білка S6 належать до родини кіназ AGC (PKA, PKG і PKC) і відіграють важливу роль у регуляції росту клітин і метаболізму [2]. Кінази S6K є ефекторами шляху mTOR, i накопичені дані свідчать про те, що активація осі mTOR/S6K контролює в клі-

(C) Т.С. Вацеба, Л.К. Соколова, В.В. Пушкарьов, О.І. Ковзун, В.М. Пушкарьов, М.Д. Тронько, 2019 


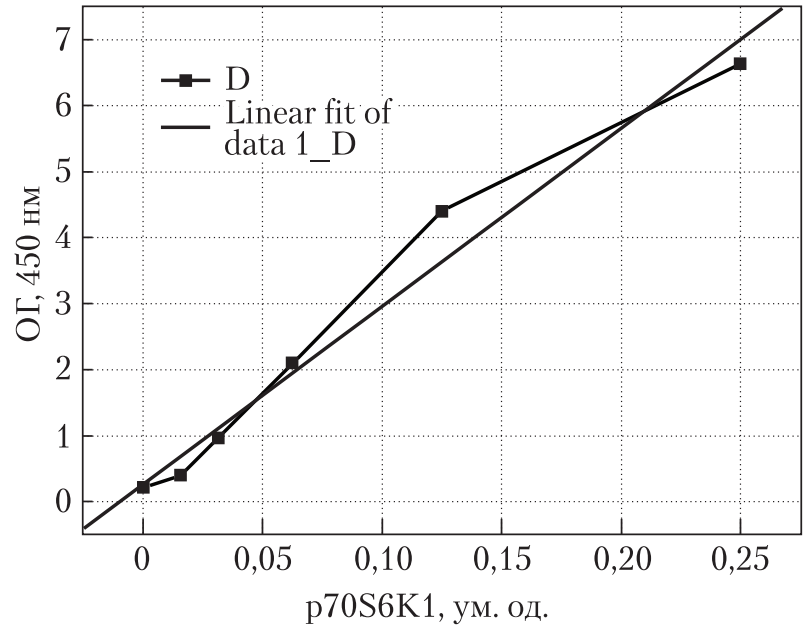

Puc. 1. Калібрувальна крива для визначення фосфорильованого по Тре389 p70S6K1

тинах процеси, пов'язані з реалізацією сигналів інсуліну та інсуліноподібного фактору росту (IGF-1) [3].

Порушення регуляції каскаду РІ3К/ Akt/mTOR/p70S6K призводить до важких захворювань, таких як рак, ожиріння і діабет 2-го типу (Д2Т) з ускладненнями [4].

До складу мононуклеарних клітин крові (РМВС) входять кілька типів клітин, які відіграють істотну роль у розвитку таких патологічних станів, як діабет та рак [5, 6]. Сигнальний шлях PI3К/Akt відіграє важливу роль у активації макрофагів та лімфоцитів, секреції ними цитокінів, виникненні в них запальних процесів та захисті пухлин від імунної системи [7].

Метою дослідження було визначення активності кінцевої ланки каскаду PI3К/Akt/ mTORC1/p70S6K у PMBC хворих на діабет 2-го типу та рак.

Матеріали та методи. Дослідження проводилося на базі відділу діабетології Ду “Інститут ендокринології та обміну речовин ім. В.П. Комісаренка НАМН України” та кафедри внутрішньої медицини № 1, клінічної імунології та алергології ДВНЗ “ІваноФранківський національний медичний університет”. Усі пацієнти підписували інформовану згоду на використання біоматеріалів у подальших діагностичних та наукових дослідженнях. Відразу ж після забору кров розводили в 2 рази $\mathrm{PBS}$ ( $\mathrm{pH} 7,4)$, нашаровували на Histopaque 1077 (“Sigma”, США), центрифугували (мікроцентрифуга Hermle Z-300)

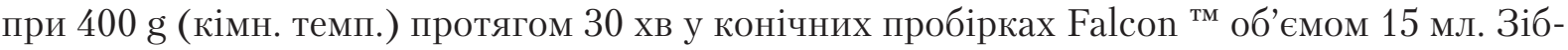
рані РВMC промивали PBS центрифугуванням при $200 \mathrm{~g}$ для видалення тромбоцитів і заморожували при $-80{ }^{\circ} \mathrm{C}$ до використання. Для визначення кількості фосфо-р70S6K1 (ф-Тре389) використовували набори для імуноферментного аналізу 85-86053 фірми “Invitrogen” (США). Клітини лізували в буфері для екстракції з набору, що містив інгібітори протеаз і фосфатаз. Дослідження проводилися в триплетах. Концентрацію білка в лізаті визначали за допомогою наборів (BCA protein assay kit) фірми "Novagen” (США). Вимірювання проводили на мікропланшетному рідері фірми “Bio-tek Instruments” (США) при довжині хвилі 450 нм.

Рівень інсуліну та IGF-1 визначали методом імуноферментного аналізу на автоматичному аналізаторі Stat fax 303+ (США) з використанням діагностичних наборів Insulin ELISA (EIA-2935) і IGF-1600 ELISA (EIA-4140) фірми “DRG” (Німеччина). Вміст HbA1c визначали методом іонообмінної хроматографії за допомогою аналізатора Bio-Rad D-10 i реактивів фірми “Вio-Rad” (США).

Калібрувальна крива (рис. 1) свідчить про задовільне узгодження експериментальної кривої з теоретичною та незначний розкид даних.

Результати експериментів представляли як $M \pm \mathrm{Std}, n=6 \div 15$. Для порівняння груп даних використовували $t$-критерій Стьюдента. Значення $P \leqslant 0,05$ вважалися вірогідними. 
Puc. 2. Кількість фосфорильованої p70S6K1 (фосфо-Тре389) у РМВС хворих на рак та діабет. 1 - контроль $(n=6) ; 2$ - пацієнти з Д2Т $(n=12)$; 3 - онкологічні хворі $(n=15) ; 4$ - пацієнти з Д2Т та раком $(n=7) . M \pm \mathrm{Std},{ }^{*}-$ відмінність від контрольної групи є вірогідною, $P<0,05 ;+-$ відмінність від груп 2 і 3 є вірогідною

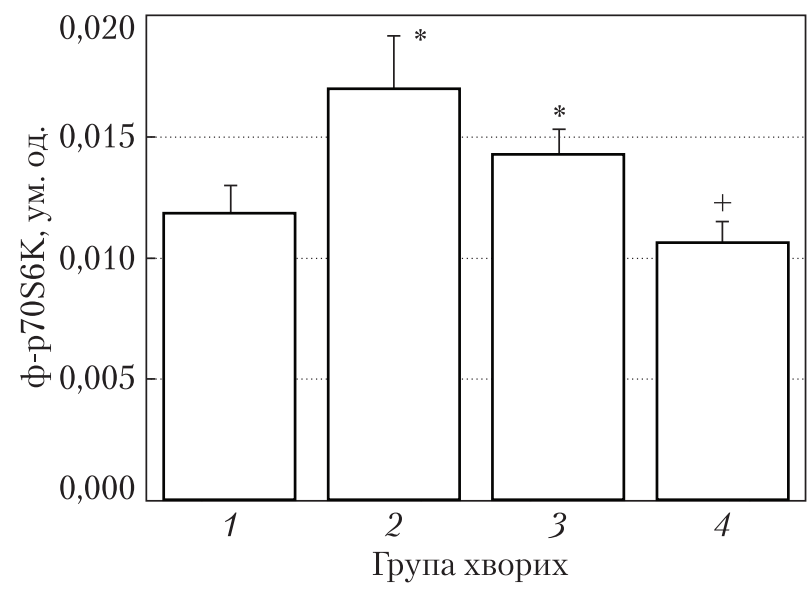

Результати та обговорення. Для досліджень були сформовані такі групи: 1 (контрольна) - здорові люди, репрезентативні за віком; 2 - хворі на Д2Т; 3 - хворі на рак; 4 - хворі на рак та Д2T. Усі пацієнти з T2D були на комбінованому лікуванні інсуліном і метформіном. Пацієнти 3 діабетом (2-га та 4-та групи) мають рівень HbA1c 7,4-9,2 \% (субкомпенсація та декомпенсація). Більшість пацієнтів з 3-ї та 4-ї груп мають рак матки, молочної залози та кишечника.

Вміст фосфо-р70S6K1 вірогідно зростає у PMBC хворих на Д2Т (рис. 2, 2), що свідчить про підвищену активність Akt/mTORC1. Підвищення рівня фосфо-p70S6K у хворих на Д2Т, крім змін внаслідок хвороби, напевно, визначається співвідношенням ефектів метформіну та інсуліну, які приймали хворі. Метформін знижує активність mTORC1 але, з іншого боку, покращує сигналінг інсуліну. Інсулін активує mTORC1 через сигнальний каскад PI3К/Akt/mTORC1 і пригнічує активацію метформіном AMPК [8], яка, у свою чергу, інгібує mTORC1. Підсумковим результатом взаємодії цих препаратів та індукованих ними сигнальних механізмів, очевидно, є активація mTORC1 i, як наслідок, p70S6K1. Активність p70S6K1 може також визначатися рівнем інсуліну та IGF-1 у крові, передача та посилення сигналу яких опосередковується каскадом PI3K/Akt/mTORC1/p70S6K1. Так, рівень інсуліну в крові хворих на діабет зростає більш ніж у 2 рази (219,46 $\pm 21,9$ \%), у хворих на діабет та рак - у 1,8 раза (182,13 \pm 26,3 \%), а рівень IGF-1 підвищується у крові хворих на рак до $161,4 \pm 22,9 \%$.

У PMBC хворих на рак також посилюється фосфорилювання p70S6K (див. рис. 2, 3), a отже, i активність mTORC1. Гіперактивація mTORC1 часто спостерігається у випадках розвитку спорадичного раку. Прискорення трансляції, викликане аберантною активацією mTORC1, призводить до збільшення розміру клітин та проліферації - двох загальних ознак раку, а пошук інгібіторів mTORC1 вважається перспективним напрямом для терапії онкологічних захворювань [9]. 3 цієї точки зору посилення активності mTORC1 у лейкоцитах викликає значний інтерес, оскільки може слугувати діагностичним маркером захворювання.

Становить інтерес зменшення активності p70S6K1 у PMBC хворих на рак та діабет (4-та група) порівняно з групами 2 та 3 (див. рис. 2, 4). Отже, у хворих останньої групи активність mTORC1 та p70S6K у лейкоцитах може бути пригніченою, порівняно з групами хворих на діабет (див. рис. 2, 2) і рак (див. рис. 2, 3). Імовірним поясненням такого пригнічення 
може бути конкуренція за спільні сигнальні механізми між інсуліном та IGF-1. Не виключена також антагоністична взаємодія між двома основними каскадами, що контролюють проліферативні процеси - РІЗК/Akt та МАРК. Відомо, що сигнальний шлях МАРК/ERK також може активувати mTORC1 [9], а надлишок інсуліну, зумовлений Д2Т, стимулює проліферативні процеси і злоякісну трансформацію через каскад Ras/MAPK/ERK1/2 [3]. Можливо також пригнічення каскаду PI3K/Akt через фосфорилювання кіназами mTORC1 i p70S6K субстрату інсулінового рецептора (IRS-1) по S307 та інших амінокислотних залишках та його деградацію, яка відбувається внаслідок тривалої гіперінсулінемії, що призводить до порушення сигнального шляху інсуліну і, отже, інсулінорезистентності [10].

Потрібно відзначити, що така ж залежність властива і експресії p70S6K в мононуклеарних клітинах крові [11], що свідчить про досить глибокі зміни в регуляторних механізмах, які беруть участь у реалізації ефектів інсуліну та IGF-1.

До складу РМВС входять моноцити/макрофаги та лімфоцити, що беруть участь у процесах клітинного та гуморального імунітету. PI3К/Akt/mTORC1 - сигнальний каскад, який значною мірою визначає функціонування цих клітин крові при діабеті та злоякісних новоутвореннях [5, 7].

p70S6K сприяє багатьом важливим клітинним процесам: синтезу білків, росту/розміру клітин, виживаності клітин, клітинному циклу і транскрипції генів, мобільності клітин, диференціюванню адипоцитів, синаптичній пластичності, контролює реакцію на пошкодження ДНК. Також p70S6K регулює два транскрипційних фактора CREMt i ER $\alpha$ [4, 12].

Дерегуляція сигналінгу через p70S6K пов’язана з різними типами раку. Було показано, що багато з кіназ, які знаходяться вище у сигнальному ланцюгу від p70S6K, часто мутують або надмірно експресуються в пухлинах, що призводить до активації p70S6K. Сигнальний каскад mTOR/p70S6K бере участь у патогенезі Д2T [4, 12].

Таким чином, стан фосфорилювання p70S6K у PMBC свідчить про активність mTORC1 та її субстратів, що може бути важливим для оцінки патологічного процесу та ефективності лікарських препаратів.

\section{ЦИТОВАНА ЛІТЕРАТУРА}

1. Yang J., Nishihara R., Zhang X., Ogino S., Qian Z.R. Energy sensing pathways: Bridging type 2 diabetes and colorectal cancer? J. Diabetes Complicat. 2017. 31, № 7. P. 1228-1236. https://doi.org/10.1016/j.jdiacomp. 2017.04.012

2. Hong S., Zhao B., Lombard D.B., Fingar D.C., Inoki K. Cross-talk between sirtuin and mammalian target of rapamycin complex 1 (mTORC1) signaling in the regulation of S6 kinase 1 (S6K1) phosphorylation. J. Biol. Chem. 2014. 289, № 19. P. 13132-13141. https://doi.org/10.1074/jbc.M113.520734

3. Тронько Н.Д., Пушкарев В.М., Соколова Л.К., Пушкарев В.В., Ковзун Е.И. Молекулярные механизмы патогенеза сахарного диабета и его осложнений. Киев: ИД “Медкнига”, 2018. 264 с.

4. Tavares M.R., Pavan I.C., Amaral C.L., Meneguello L., Luchessi A.D., Simabuco F.M. The S6K protein family in health and disease. Life Sci. 2015. 131. P. 1-10. https://doi.org/10.1016/j.lfs.2015.03.001

5. de Oliveira C.E., Oda J.M., Losi Guembarovski R., de Oliveira K.B., Ariza C.B., Neto J.S., Banin Hirata B.K., Watanabe M.A. CC chemokine receptor 5: the interface of host immunity and cancer. Dis. Markers. 2014. 2014. 126954. https://doi.org/10.1155/2014/126954

6. Sokolova L.K., Pushkarev V.M., Pushkarev V.V., Tronko N.D. Diabetes and atherosclerosis. Cellular mechanisms of pathogenesis. Endokrinologia. 2017. 22, № 2. P. 127-138.

7. Dituri F., Mazzocca A., Giannelli G., Antonaci S. PI3K functions in cancer progression, anticancer immunity and immune evasion by tumors. Clin. Dev. Immunol. 2011. 2011. 947858. https://doi.org/10.1155/2011/947858 
8. Sokolova L.K., Pushkarev V.M., Belchina Y.B., Pushkarev V.V., Tronko N.D. Effect of combined treatment with insulin and metformin on 5'AMP-activated protein kinase activity in lymphocytes of diabetic patients. Допов. Нац. акад. наук Укр. 2018. № 5. С. 100-104. https://doi.org/10.15407/dopovidi2018.05.100

9. Kim L.C., Cook R.S., Chen J. mTORC1 and mTORC2 in cancer and the tumor microenvironment. Oncogene. 2017. 36, № 16. P. 2191-2201. https://doi.org/10.1038/onc.2016.363

10. Пушкарев В.М., Соколова Л.К., Пушкарев В.В., Тронько Н.Д. Роль АМРК и mTOR в развитии инсулинорезистентности и диабета 2 типа. Механизм действия метформина. Пробл. ендокрин. патол. 2016. № 3. C. $77-90$.

11. Vatseba T.S., Sokolova L.K., Pushkarev V.V., Kovzun O.I., Pushkarev V.M., Tronko M.D. Expression of protein kinase p70S6K in leukocytes of patients with cancer and diabetes. Ендокринологія. 2019. 24, № 1. C. $26-30$.

12. Bahrami B.F., Ataie-Kachoie P., Pourgholami M.H., Morris D.L. p70 Ribosomal protein S6 kinase (Rps6kb1): an update.J. Clin. Pathol. 2014. 67, № 12. P. 1019-1025. https://doi.org/10.1136/jclinpath-2014-202560

Надійшло до редакції 25.03.2019

\section{REFERENCES}

1. Yang, J., Nishihara, R., Zhang, X., Ogino, S. \& Qian, Z. R. (2017). Energy sensing pathways: Bridging type 2 diabetes and colorectal cancer? J. Diabetes Complicat., 31, No. 7, pp. 1228-1236. https://doi.org/10.1016/j. jdiacomp.2017.04.012

2. Hong, S., Zhao, B., Lombard, D. B., Fingar, D. C. \& Inoki, K. (2014). Cross-talk between sirtuin and mammalian target of rapamycin complex 1 (mTORC1) signaling in the regulation of S6 kinase 1 (S6K1) phosphorylation. J. Biol. Chem., 289, No. 19, pp. 13132-13141. https://doi.org/10.1074/jbc.M113.520734

3. Tronko, N. D., Pushkarev, V. M., Sokolova, L. K., Pushkarev, V. V. \& Kovzun, O. I. (2018). Molecular mechanisms of pathogenesis of diabetes and its complications. Kyiv: Medkniga (in Russian).

4. Tavares, M. R., Pavan, I. C., Amaral, C. L., Meneguello, L., Luchessi, A. D. \& Simabuco, F. M. (2015). The S6K protein family in health and disease. Life Sci., 131, pp. 1-10. https://doi.org/10.1016/j.lfs.2015.03.001

5. de Oliveira, C. E., Oda, J. M., Losi Guembarovski, R., de Oliveira, K. B., Ariza, C. B., Neto, J. S., Banin Hirata, B. K. \& Watanabe, M. A. (2014). CC chemokine receptor 5: the interface of host immunity and cancer. Dis. Markers., 2014, 126954. https://doi.org/10.1155/2014/126954

6. Sokolova, L. K., Pushkarev, V. M., Pushkarev, V. V. \& Tronko, N. D. (2017). Diabetes and atherosclerosis. Cellular mechanisms of pathogenesis. Endokrinologia, 22, No. 2, pp. 127-138.

7. Dituri, F., Mazzocca, A., Giannelli, G. \& Antonaci, S. (2011). PI3K functions in cancer progression, anticancer immunity and immune evasion by tumors. Clin. Dev. Immunol., 2011, 947858. https://doi.org/10.1155/ 2011/947858

8. Sokolova, L. K., Pushkarev, V. M., Belchina, Y. B., Pushkarev, V. V. \& Tronko, N. D. (2018). Effect of combined treatment with insulin and metformin on $5^{\prime}$ AMP-activated protein kinase activity in lymphocytes of diabetic patients. Dopov. Nac. akad. nauk Ukr., No. 5, pp. 100-104. https://doi.org/10.15407/dopovidi2018.05.100

9. Kim, L. C., Cook, R. S. \& Chen J. (2017). mTORC1 and mTORC2 in cancer and the tumor microenvironment. Oncogene, 36, No. 16, pp. 2191-2201. https://doi.org/10.1038/onc.2016.363

10. Pushkarev, V. M., Sokolova, L. K., Pushkarev, V. V. \& Tronko, M. D. (2016). The role of AMPK and mTOR in the development of insulin resistance and type 2 diabetes. The mechanism of metformin action (literature review). Probl. Endocrin. Pathol., No. 3, pp. 77-90 (in Russian).

11. Vatseba, T. S., Sokolova, L. K., Pushkarev, V. V., Kovzun, O. I., Pushkarev, V. M. \& Tronko, M. D. (2019). Expression of protein kinase p70S6K in leukocytes of patients with cancer and diabetes. Endokrinologia, 24, No. 1, pp. 26-30.

12. Bahrami, B. F., Ataie-Kachoie, P., Pourgholami, M. H. \& Morris, D. L. (2014). p70 Ribosomal protein S6 kinase (Rps6kb1): an update. J. Clin. Pathol., 67, No. 12, pp. 1019-1025. https://doi.org/10.1136/jclinpath2014-202560

Received 25.03.2019 
Т.С. Вацеба ${ }^{1}$, Л.К. Соколова ${ }^{2}$, В.В. Пушкарев ${ }^{2}$,

Е.И. Ковзун ${ }^{2}$, В.М. Пушкарев ${ }^{2}$, Н.Д. Тронько ${ }^{2}$

${ }^{1}$ ГВУз “Ивано-Франковский национальний медицинский университет"

${ }^{2}$ ГУ “Институт ендокринологии и обмена веществ им. В.П. Комисаренко НАМН Украины”, Киев

E-mail: pushkarev.vm@gmail.com

АКТИВАЦИЯ ПРОТЕИНКИНАЗЫ P70S6К1

В МОНОНУКЛЕАРНЫХ КЛЕТКАХ ПЕРИФЕРИЧЕСКОЙ

КРОВИ БОЛЬНЫХ РАКОМ И ДИАБЕТОМ

Сигнальный каскад IRS/PI3K/Akt/mTOR/p70S6K контролирует рост клеток и гомеостаз в ответ на сигналы среды, такие как уровень аминокислот, глюкозы, энергии, кислорода, и действие ростовых факторов. Конечным звеном этого каскада является протеинкиназа p70S6K, которая контролирует синтез белка, биогенез рибосом, клеточный цикл, апоптоз, сплайсинг мРНК и другие важные процессы. Нарушение регуляции каскада PI3K/Akt/mTOR/p70S6K может привести к таким тяжелым заболеваниям, как рак, ожирение и диабет 2-го типа с осложнениями.

Изучали активацию p70S6K1 в мононуклеарных клетках периферической крови (PMBC) больных раком и диабетом методом иммуноферментного анализа. Показано, что в РМВС больных раком и диабетом фосфорилирование p70S6K1 (Тре389) возрастает, что свидетельствует об активации киназы, которая играет важную роль в формировании инсулинорезистентности и прогрессии опухолей. Возможно, это связано с повышенным уровнем инсулина и IGF-1 в крови этих больных. Однако у онкологических больных диабетом фосфорилирование p70S6K1 и, соответственно, ее активность существенно снижаются по сравнению с показателями у больных раком или диабетом. Обсуждаются механизмы такого снижения активации p70S6K1.

Ключевые слова: диабет 2-го типа, рак, мононуклеарные клетки периферической крови, p70S6K1.

T.S. Vatseba ${ }^{1}$, L.K. Sokolova ${ }^{2}$, V.V. Pushkarev ${ }^{2}$, O.I. Kovzun ${ }^{2}$, V.M. Pushkarev ${ }^{2}$, M.D. Tronko ${ }^{2}$

${ }^{1}$ Ivano-Frankivsk National Medical University

${ }^{2}$ V.P. Komisarenko Institute of Endocrinology and Metabolism of the NAMS of Ukraine, Kyiv

E-mail: pushkarev.vm@gmail.com

\section{ACTIVATION OF PROTEIN KINASE P70S6K1 IN PERIPHERAL} BLOOD MONONUCLEAR CELLS OF PATIENTS WITH CANCER AND DIABETES

The IRS/PI3K/Akt/mTOR/p70S6K signaling cascade controls the cell growth and homeostasis in response to environmental signals such as levels of amino acids, glucose, energy, oxygen, and action of growth factors. The final link of this cascade is protein kinase p70S6K, which controls the protein synthesis, ribosomal biogenesis, cell cycle, apoptosis, splicing of mRNA, and other important processes. Disturbance of the IRS/PI3K/Akt/mTOR/ p70S6K cascade regulation can lead to serious diseases such as cancer, obesity and type 2 diabetes with complications.

We study the activation of p70S6K1 in peripheral mononuclear blood cells (PMBC) of patients with cancer and diabetes by immunoenzyme analysis. It has been shown that, in PMBC patients with cancer and diabetes, the phosphorylation of p70S6K1 (Thr389) increases, indicating the activation of a kinase, which plays an important role in the formation of insulin resistance and tumor progression. Perhaps, this is due to elevated levels of insulin and IGF-1 in blood of these groups. However, in cancer patients with diabetes, the phosphorylation of p70S6K1 and, accordingly, its activity are significantly reduced compared with groups of patients with cancer or diabetes. The mechanisms for such a decrease in p70S6K1 activation are discussed.

Keywords: type 2 diabetes, cancer, peripheral mononuclear blood cells, p70S6K1. 